\title{
Article \\ Knowledge and practice about prevention on Hepatitis-B virus infection among the student nurses
}

\author{
Muhammad Nurul Islam ${ }^{1,2^{*}}$ and Kazi Jahangir Hossain ${ }^{2}$ \\ ${ }^{1}$ Department of Nursing, Sylhet Shahid Shamsuddin Ahmed Hospital, Sylhet-3100, Bangladesh \\ ${ }^{2}$ Department of Health Education, National Institute of Preventive and Social Medicine (NIPSOM), \\ Mohakhali, Dhaka-1212, Bangladesh
}

*Corresponding author: Muhammad Nurul Islam, Staff Nurse, Sylhet Shahid Shamsuddin Ahmed Hospital, Sylhet-3100, Bangladesh. Phone: +880-1720-199825; Email: islambd2000@yahoo.com

Received: 01 November 2021/Accepted: 21 December 2021/ Published: 30 December 2021

Copyright (C) 2021 Muhammad Nurul Islam and Kazi Jahangir Hossain. This is an open access article distributed under the Creative Commons Attribution 4.0 International License (https://creativecommons.org/licenses/by/4.0/), which permits unrestricted use, distribution, and reproduction in any medium, provided the original work is properly cited.

\begin{abstract}
The silent killer Hepatitis-B is a major threat to public health throughout the world and well recognized occupational risk for healthcare workers. Good knowledge and practice about hepatitis- B virus (HBV) infection prevention is crucial for HBV infection control. In Bangladesh, there were few studies conducted regarding the knowledge and practice level of student nurses' about HBV infection prevention. The purpose of this study was to assess the knowledge and practice level of student nurses' about HBV infection prevention in Bangladesh. A cross-sectional descriptive type of study was conducted in three nursing colleges at Sylhet in Bangladesh. A pre-tested self-administered structured questionnaire with observation checklist was constructed and implemented to assess knowledge and practice about HBV infection prevention. A total of 150 student nurses' from three nursing college were participated in this study. Data were analyzed using descriptive statistics and Chi-square test was used implemented to determine the relationship between categorical variables. The result shows that most of the respondents (83.3\%) were female and mean age was $20 \pm 8.72$ years. The level of knowledge was good $(81.07 \%)$ and practice level was satisfactory $(72.22 \%)$ on HBV infection prevention related activities. Most of the respondents had accurate concepts about HBV infection can be prevented by $96 \%$ vaccination, $83.33 \%$ safe sex, $92.63 \%$ use of disposable syringe, $84.67 \%$ wearing gloves during patient care and $78 \%$ promote public awareness. The study findings concluded that the majority of the respondents had good knowledge and satisfactory practice level in HBV infection prevention. However, not all of them with good knowledge carried out good practices about to HBV infection prevention in their working place. Authority should be ensuring vaccination status and periodical training program to maintain continued good level of knowledge and practice for prevention HBV infection.
\end{abstract}

Keywords: Hepatitis-B; knowledge; practice; prevention; student nurses

\section{Introduction}

The silent killer Hepatitis-B is a major threat to public health throughout the world (WHO, 2020) and well recognized occupational risk for healthcare workers (Mehriban et al., 2016; Akazong et al., 2020). Hepatitis-B is an inflammatory disease of liver caused by the Hepatitis B DNA virus, which is transmitted through percutaneous or mucosal exposure to infection blood or body fluids (CDC, 2021). HBV infection is confirmed 
by laboratory test focuses on the detection of hepatitis-B surface antigen HBsAg (WHO, 2020). It can lead to lifelong chronic infection, resulting in cirrhosis of the liver, liver cancer, liver failure and death (Lim et al., 2020; CDC, 2021). Chronically infected HBV carriers are able to transmit HBV through contact with their body fluids, which includes occupational exposure to their blood secretions, sexual intercourse (WHO, 2020). People at risk include healthcare workers (HCWs) in contact with blood and human secretions, haemodialysis staff, oncology and chemotherapy nurses, all personnel at risk of needle stick and sharp injuries which includes those working in operating rooms and clinical laboratories, respiratory therapists, surgeons, doctors, dentists, as well medical, dental, health technology and also nursing students (Perez-Diaz et al., 2015; Demsiss et al., 2018). Hepatitis-B infection is a dreaded disease; its prevalence varies from country to country and depends upon a complex mix of behavioral, environmental and host factors. Bangladesh and the Indian sub-continent as a whole, together with the Middle-East, North-Africa and former Soviet Union, belongs to the intermediate prevalence region of HBV infection (Al-Mahtab, 2015; Hasan et al., 2017; Choudhuri et al., 2019). Based on review, there is no specific treatment for acute Hepatitis-B (WHO, 2020). Prevention is the only safeguard against epidemic of viral hepatitis. Knowing facts and having proper attitudes and behaviors are critical to prevent the spread of this infection (Balegha et al., 2021; Akazong et al., 2020). To make it more effective, we need to assess gaps in health education (Hasan et al., 2017). Such information will serve as a guide for development of information, education and communication activities for prevention and control of Hepatitis-B. The vaccine against Hepatitis-B is $95 \%$ to $98.8 \%$ effective in preventing $\mathrm{HBV}$ infection and its chronic complications (Chang et al, 2015; Hossain et al., 2018). But in chronic HBV infection can be treated with medication including anti-viral oral drugs (WHO, 2020). According to global statistics, nearly two billion people infected with Hepatitis-B virus and about 391 million or 5\% world people live with chronic HBV infection worldwide (Collaborators, 2018). Each year 3o million people become newly infected HBV infection globally (Hepatitis-B Foundation, 2021). It is estimated that current global chronic HBV prevalence has shows $3.5 \%$ to $5.6 \%$ across all ages (Schmit et al., 2021). An estimated 887,000 die due to consequences of HBV infection, from cirrhosis and liver cancer (WHO, 2020).

In Bangladesh, prevalence of Hepatitis-B has been estimated 5.5\% (Health Bulletin 2019, 2020 p.84). Based on our country's studies, prevalence of risky group has noted 7-7.5\% among the injection drug user, $7.96 \%$ health workers, 6.5\% Thalassemic patients, and 3.84\% tea gardeners (Al-Mahtab et al., 2017; Uz-zaman et al., 2018). The prevalence of HBV infection among HCWs shows 2-10 times higher than general population in globally (Abdela et al., 2016). Review from previous study in Ethiopia found prevalence of HBsAg among medical, nursing and health sciences students has noted 4.2\% (Demsiss et al., 2018). Review found that HCWs especially nurses are high risk for occupational blood borne pathogens (Perez-Diaz et al., 2015; Abdela et al., 2016). Nursing students are more risky to HB due to they are in direct contact with the patients for management and nursing care in clinical settings. A study from Turkey found that $35.5 \%$ nursing students had experienced a needlestick injury and $66 \%$ had injured by ampoule during clinical practice training. Unexpectedly, it was also found that this thing is responsible for $20 \%$ of the injury had been in contact with patients' blood or body fluid (Karadag, 2010).

Nursing profession is the fundamental part of healthcare team. Student nurses are pupil of the nursing profession and lead to future generation in healthcare services. They will also role transition student nurse to staff nurse in tomorrow nursing world. Proper knowledge and practice is essential for prevention of spread of infection and safety precaution. Based on global studies, nursing students preventive knowledge, attitude and practice on HBV has found good (Reang et al., 2015; Demsiss et al., 2018; Gebremeskel et al., 2020), positive (Abdela et al., 2016; Nalii et al., 2017), and satisfactory (Modawi et al., 2020; Gebremeskel et al., 2020) respectively. Although, other studies had found low level of knowledge (Modawi et al., 2020), poor attitude (Modawi et al., 2020), and poor level of practice (Reang et al., 2015; Abdela et al., 2016; Demsiss et al., 2018). In Bangladesh previous studies were done about registered nurses preventive knowledge and practice about Hepatitis-B who working in different level of public and private hospitals in Dhaka (Mehriban et al., 2015; Khan et al., 2017). However, there is little known about student nurses knowledge and practice on prevention of HBV infection during their academic period in Bangladesh. Therefore, this study is warranted to explore of the current level of knowledge and practice for prevention of HBV infection. This study findings will helps nurses to gain knowledge, attitude, and precaution to avoid becoming infected HBV infection and others dreadful diseases.

\section{Materials and methods}

\subsection{Study design}

This is a Descriptive cross-sectional study. 


\subsection{Study population}

The study population was nursing students of nursing colleges in Sylhet.

\subsection{Study places}

This study was carried out from three nursing colleges at Sylhet District namely Sylhet Nursing College attached Sylhet MAG Osmani Medical College Hospital, Begum Rabeya Khatun Chowdhury (BRKC) Nursing College attached Jalalabad Ragib Rabeya Medical College Hospital, and North-East Nursing College attached North-East Medical College Hospital, Sylhet. Approximately, a total of 420 students were selected from three nursing colleges.

\subsection{Study period}

Total duration of study was from January 2012 to June 2012.

\subsection{Sample size}

A sample size of 150 was calculated based 50\% unknown prevalence with an absolute error of $8 \%$.

\subsection{Sampling technique}

Student nurses were selected from three nursing colleges using a proportional random sampling process. The sample technique was selected through simple random sampling and maintains proper inclusion and exclusion criteria.

\subsection{Tool of the study}

A pre-tested self-administer questionnaire were distributed to collected information. Section A assessed the socio-demographic characteristics of the respondents with 10 questions, covering age, sex, religion, education, name of nursing college, family income, family history of HBV infection and vaccine status. Section B covered with 11 questions related to knowledge on prevention of HBV infection viz, sources, types, mode of transmission, clinical features, risk person, investigation, complications, and ways of prevention etc., which as answer were multiple responses. The level of knowledge part had been scored into three categories, likes poor $(<20)$, satisfactory (20-40), and good (>40). In addition, an observational checklist added by Principal Investigator (PI) to evaluate level of practice of students nurses during clinical practice training.

\subsection{Data analysis}

After completion of final data collection then data were checked thoroughly and cleaned followed by editing, coding, and categorizing to detect errors or emissions and to maintain consistency and validity. The data were entered in computer with a statistical software package of SPSS windows version 16 for analysis and interpretation. Both descriptive and Bivarate analysis were done. Values were expressed are frequencies and percentages. Non-parametric Pearson's Chi-Square $\left(\chi^{2}\right)$ test was carryout to explore the relationship between Hepatitis-B and Socio-demographic status of the respondents. A p value $<0.5$ was considered statistically significant.

\subsection{Ethical procedures}

The study protocol was approved by the Ethical Review Committee of National Institute of Preventive and Social Medicine (NIPSOM), Dhaka. Before data collection, written permission was taken from the Administrative Head of the selected Nursing Colleges and Hospitals. The participation is this study was voluntary and informed consent was obtained. The participants were briefed about the aims and benefits of the study. They also informed and ensured that data will keep in confidentially and they have rights to withdraw of $\mathrm{him} / \mathrm{her}$ without any excuses or condition.

\section{Results}

Table 1 shows that most (68.7\%) of respondent's education level was Diploma in Nursing Program. Majority $(83.3 \%)$ of the respondents were female. Near half of them (49.7\%) of the respondents were belong to 20-30 years. Major portion (75.3\%) of the respondents was Muslim. More than half (54.7\%) of the respondents was from Sylhet Nursing College. It was observed that nearly forty percent and above one third (37.3\%) had income below BDT 10000 and one fourth (24.7\%) to one fifth (21\%) respondents had BDT 1000-20000 and BDT 20001- 30000 respectively. Most (80.0\%) of the respondents had family history of negative of HBV infection. 
Figure 1 shows that above than two third $(67.30 \%)$ of the respondents were not vaccinated, $12 \%$ complete vaccinated and $21.70 \%$ respondents were partially $\mathrm{HB}$ vaccinated.

Table 2 shows that regarding types of Hepatitis, most (92\%) of the respondents answered Hepatitis-B prevalent in our country. Majority (90.67\%) answered Hepatitis-B is serious types of Hepatitis. Most $(93.33 \%)$ of the respondents knew the blood borne and sexual transmitted disease (STD) (89.33\%) is the sources of HBV infection. Besides, most (96\%) of the respondents answered mode of transmission of HB Virus is through blood transfusion, sexual intercourse $(89.33 \%)$, and use of contaminated syringes, needles (88\%) and also transplacental route $(83.33 \%)$. Nurses appeared to be the highest $(89.33 \%)$ risk person of HBV infection followed by doctor $(78.67 \%)$, multiple injecting drug user $(82.67 \%)$, and sexual worker $(85.33 \%)$. Regarding symptoms of HBV infection, most of the respondents answered were yellow coloration of sclera (92\%), followed by yellow coloration of urine (92.67\%), weakness (90\%), and anorexia (84.67\%). Majority (95.33\%) of the respondents know the complication of HBV infection is cirrhosis of liver, loss of immunity (88.67\%), and liver cancer (70\%). A large portion (86.0\%) of the students answered HBsAg is the investigation for HBV infection. Most (96\%) of the respondents know the vaccination is the way prevention of transmission of HBV infection. Then they also answered use of disposable syringe and needles (92.67\%), blood transfusion through screening (88.67\%), use of gloves (84.67\%), and safe sexual relationship (83.33\%). Majority of the students (91.90\%) were always strictly checking during blood transfusion and most (96\%) of them discarded HBV infected syringe and needles. Use of sterile instruments can be prevention of HBV infection in healthcare setting. Most of the respondents answered use in operational activities (99.33\%), followed by dressing (98\%), and catheterization $(91.33 \%)$. Most of the students answered wearing of gloves during patients delivery (98\%), dressing (94\%), and during patients care $(91.33 \%)$. Most of the students reported they do in duty hour's toward HBV infected patients sympathy and cooperation (93.33\%), maintain isolation $(91.33 \%)$, self protection from needle stick injury (94\%), and use of gloves nursing care (84.67\%). Majority of the students reported about advice of HBV infected patients take appropriate treatment (93.33\%), use of condom in sexual intercourse (96\%), and use of separate utensils likes brush, razor etc.(87.33\%). To promote public awareness, most of the respondents say to regular advertisement in media (98\%), awareness professional group (94\%), students group (91\%), and also strengthening community health services $(87.33 \%)$.

Table 3 shows that overall composite score $81.33 \%$ about prevention of HBV infection. According to study findings, evaluation of 90 student nurses does practice on prevention of HBV infection in working place out of 150 respondents. Ninety students (100\%) do performed Hand washing and use of disposable syringe. Most (93.33\% to $73.80 \%$ ) of respondents do practice awareness during blood transfusion, wearing gloves, use of sterile instruments, and practice of medical waste discarded in proper way. However, unexpectedly found that below half $(42.22 \%)$ of the respondents practices of wearing PPE namely mask, cap, gown during delivery and assist in Operation Room.

Table 4 shows that most $(81.07 \%)$ of the respondents had good level knowledge about prevention on HBV infection. PI observed that the daily practice on different issues of infection prevention related activities among student nurses in working/training place. Majority (72.22\%) respondents performed do satisfactory level practice for prevention of HBV infection.

Table 5 shows that practice on prevention of HBV infection was significant positive relationship with education ( $\mathrm{p}<.005)$. However, others had no significant relationship between practice of transmission and prevention of HBV infection with gender and ages of the respondents ( $p>.05)$.

The above Table 6 shows that no statistical significant association was found between knowledge and practice regarding prevention of $\mathrm{HBV}$ infection ( $\mathrm{p}>.05)$. 
Asian J. Med. Biol. Res. 2021, 7 (4)

Table 1. Distribution of Socio-demographic characteristics of the respondents.

\begin{tabular}{|l|l|l|}
\hline Name of variables & Frequency & Percent (\%) \\
\hline <20 Years & & \\
\hline 20-30 Years & 47 & 31.3 \\
\hline 30-40 Years & 74 & 49.7 \\
\hline Sex Years & 20 & 13.3 \\
\hline Female & 9 & 6.0 \\
\hline Religion & & \\
\hline Muslim & 125 & 83.3 \\
\hline Non-Muslim & 25 & 16.7 \\
\hline Education & & \\
\hline Diploma in Nursing & 113 & 75.3 \\
\hline Post-Basic B.Sc in Nursing & 37 & 24.7 \\
\hline Students of Nursing College & & \\
\hline Sylhet Nursing College & 103 & 68.7 \\
\hline North-East Nursing College & 47 & 31.3 \\
\hline BRKC Nursing College & & \\
\hline Family Income (BDT) & 82 & 54.7 \\
\hline$<10000$ & 47 & 31.3 \\
\hline 10001-20000 & 21 & 14.0 \\
\hline 20001-30000 & & \\
\hline 30001-4000 & 56 & 37.30 \\
\hline (40000 & 37 & 24.70 \\
\hline Positive & 31 & 21.0 \\
\hline Negative & 20 & 13.30 \\
\hline Not known & 6 & 4.00 \\
\hline & & \\
\hline & 12 & 8.1 \\
\hline & 120 & 80.0 \\
\hline & 16 & 10.8 \\
\hline
\end{tabular}

\section{Hep atitis-B Vaccinated Status}

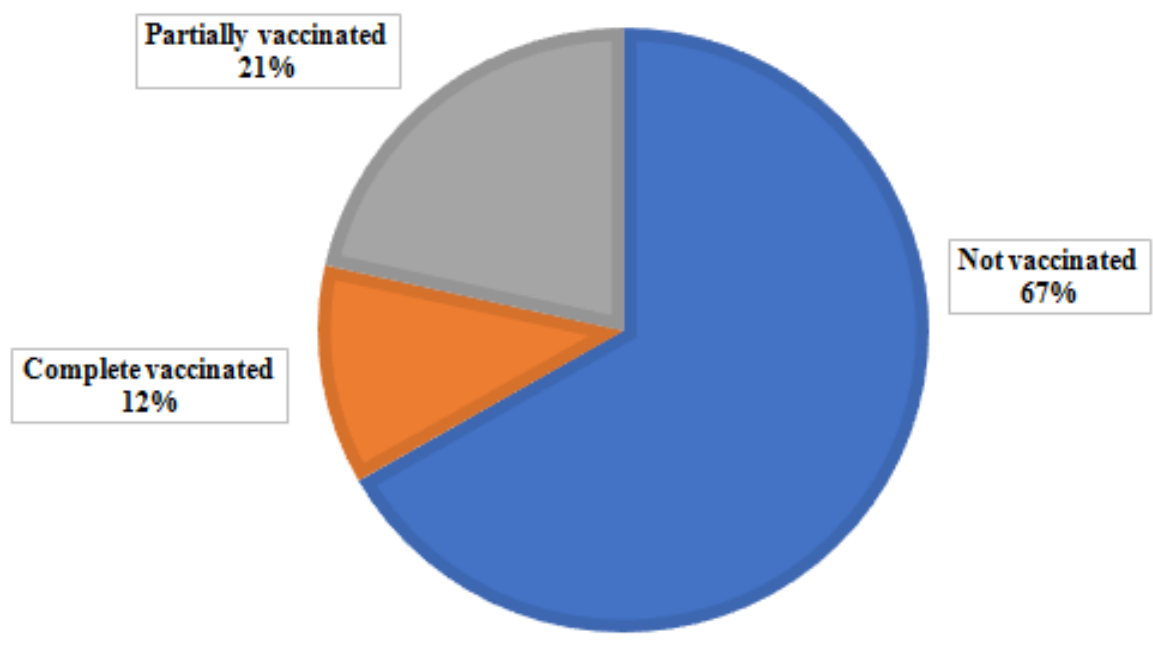

Figure 1. Hepatitis-B vaccinated status. 
Asian J. Med. Biol. Res. 2021, 7 (4)

Table 2: Distribution of knowledge about concept of Hepatitis-B.

\begin{tabular}{|c|c|c|c|}
\hline \multicolumn{2}{|r|}{ Name of Variables } & Frequency & Percent (\%) \\
\hline \multirow[t]{3}{*}{ 1. Types of Hepatitis } & Hepatitis-A & 125 & 83.33 \\
\hline & Hepatitis-B & 138 & 92.0 \\
\hline & Hepatitis-C & 87 & 57.33 \\
\hline \multirow[t]{3}{*}{ 2. Serious types of Hepatitis } & Hepatitis-B & 136 & 90.67 \\
\hline & Hepatitis-C & 77 & 51.33 \\
\hline & Hepatitis-A & 14 & 9.33 \\
\hline \multirow[t]{4}{*}{ 3. Sources of Hepatitis-B } & Blood borne & 140 & 93.33 \\
\hline & STD & 134 & 89.93 \\
\hline & Water borne & 52 & 32.67 \\
\hline & Air borne & 5 & 3.33 \\
\hline \multirow[t]{7}{*}{ 4. Modes of transmission } & Through blood transfusion & 144 & 96 \\
\hline & Sexual intercourse with infected person & 134 & 89.33 \\
\hline & Use of contaminated syringes and needles & 132 & 88 \\
\hline & Trans-placental route (Mother to Baby) & 125 & 83.33 \\
\hline & Contaminated blade/razor & 82 & 54.67 \\
\hline & Through insect bit (Mosquito, lice, flea) & 56 & 37.33 \\
\hline & During nursing care of HBV infected person & 89 & 59.33 \\
\hline \multirow[t]{9}{*}{ 5. Risk of Hepatitis-B } & Nurse & 134 & 89.33 \\
\hline & Doctor & 118 & 78.67 \\
\hline & Dental Surgeon & 79 & 52.67 \\
\hline & Medical Technologist & 86 & 57.33 \\
\hline & Multiple injected drug user & 124 & 82.67 \\
\hline & Professional blood donor & 121 & 80.67 \\
\hline & Sexual worker & 128 & 85.33 \\
\hline & Close relatives & 112 & 74.67 \\
\hline & Repeated blood transfusion & 103 & 68.67 \\
\hline \multirow[t]{5}{*}{ 6. Symptoms of Hepatitis-B } & Yellow coloration of sclera & 138 & 92.00 \\
\hline & Weakness & 135 & 90.00 \\
\hline & Yellow coloration of urine & 139 & 92.67 \\
\hline & Anorexia & 127 & 84.67 \\
\hline & Ascities & 14 & 9.33 \\
\hline \multirow{5}{*}{$\begin{array}{l}\text { 7. Complications of } \\
\text { Hepatitis-B }\end{array}$} & Jaundice & 124 & 82.67 \\
\hline & Loss of immunity & 133 & 88.67 \\
\hline & Cirrhosis of liver & 95 & 95.33 \\
\hline & Liver cancer & 105 & 70.00 \\
\hline & Don't know & 8 & 5.33 \\
\hline \multirow{3}{*}{$\begin{array}{l}\text { 8. Investigation of } \\
\text { Hepatitis-B }\end{array}$} & HBsAg & 129 & 86.00 \\
\hline & Blood Grouping & 8 & 5.33 \\
\hline & Urine & 13 & 8.66 \\
\hline \multirow{8}{*}{$\begin{array}{l}\text { 9. Ways of prevention of } \\
\text { transmission }\end{array}$} & Vaccination & 144 & 96.00 \\
\hline & Safe sexual relationship & 125 & 83.33 \\
\hline & Use of disposable syringe and needles & 139 & 92.67 \\
\hline & Blood transfusion through screening & 133 & 88.67 \\
\hline & Use of gloves & 127 & 84.67 \\
\hline & Hand washing & 95 & 63.33 \\
\hline & Promote public awareness & 117 & 78.00 \\
\hline & Improve sanitation & 42 & 28.00 \\
\hline \multirow{3}{*}{$\begin{array}{l}\text { 10.Checking of Blood } \\
\text { transfusion }\end{array}$} & Always & 137 & 91.9 \\
\hline & Often & 8 & 5.4 \\
\hline & Sometimes & 5 & 2.7 \\
\hline \multirow{3}{*}{$\begin{array}{l}\text { 11.HBV infected Syringes } \\
\text { and Needles }\end{array}$} & Discarded & 144 & 96.00 \\
\hline & Restore & 4 & 2.67 \\
\hline & Disinfection and reuse & 2 & 1.33 \\
\hline
\end{tabular}




\begin{tabular}{|c|c|c|c|}
\hline \multirow[t]{5}{*}{ 12.Use of sterile instruments } & Dressing & 147 & 98.00 \\
\hline & Patient's delivery & 146 & 97.33 \\
\hline & Catheterization & 137 & 91.33 \\
\hline & Operational activities & 149 & 99.33 \\
\hline & Nursing care & 116 & 77.33 \\
\hline \multirow[t]{5}{*}{ 13.Use of gloves } & Dressing & 141 & 94.00 \\
\hline & During patients care & 137 & 91.33 \\
\hline & Before blood drawing & 101 & 67.33 \\
\hline & Patients delivery & 147 & 98.00 \\
\hline & Blood transfusion & 89 & 59.33 \\
\hline \multirow{6}{*}{$\begin{array}{l}\text { 14.Duties for Hepatitis-B } \\
\text { patients in ward }\end{array}$} & Inform everybody & 129 & 86.00 \\
\hline & Isolation & 137 & 91.33 \\
\hline & Use of gloves during care & 127 & 84.67 \\
\hline & Self protection from needle stick injury & 141 & 94.00 \\
\hline & Blood and body fluid discarded in proper place & 134 & 89.33 \\
\hline & Sympathy and cooperation & 140 & 93.33 \\
\hline \multirow{6}{*}{$\begin{array}{l}\text { 15.Advice for Hepatitis-B } \\
\text { patients }\end{array}$} & Taking vaccine & 109 & 73.67 \\
\hline & Separation & 124 & 82.67 \\
\hline & Use of condom in sexual intercourse & 144 & 96.00 \\
\hline & Avoid blood donation & 99 & 66.00 \\
\hline & Appropriate treatment & 140 & 93.33 \\
\hline & Sue separate utensils & 131 & 87.33 \\
\hline \multirow{6}{*}{$\begin{array}{l}\text { 16.Steps for public } \\
\text { awareness }\end{array}$} & Regular advertisement in media & 147 & 98.00 \\
\hline & Awareness risky people & 124 & 82.67 \\
\hline & Strengthening community health services & 131 & 87.33 \\
\hline & Awareness professional group & 141 & 94.00 \\
\hline & Awareness students group & 137 & 91.33 \\
\hline & Door to door education services & 59 & 39.33 \\
\hline
\end{tabular}

*Multiple responses

Table 3. Observational Checklist for Practice by Student Nurses regarding prevention of HBV infection $(\mathbf{n}=90)$.

\begin{tabular}{|l|l|l|}
\hline Practice Issues & Performed & Percent (\%) \\
\hline Hand washing before and after nursing activities & 90 & 100 \\
\hline $\begin{array}{l}\text { Barrier methods in nursing care (Isolation of HBV positive patients, Red marking } \\
\text { in patient's bed etc.) }\end{array}$ & 55 & 61.11 \\
\hline Use of disposable syringes & 90 & 100 \\
\hline Use of sterile instruments during dressing & 84 & 93.33 \\
\hline $\begin{array}{l}\text { Wearing of gloves (during blood drawing, blood transfusion, dressing, handling } \\
\text { and giving nursing care) }\end{array}$ & 79 & 87.78 \\
\hline Wearing mask, cap, gown, during delivery, and assist in operation room & 38 & 42.22 \\
\hline $\begin{array}{l}\text { Awareness during blood transfusion (Eg: Check blood bag, blood group, } \\
\text { registration no., screening test, right patients) }\end{array}$ & 88 & 97.55 \\
\hline $\begin{array}{l}\text { Practice of medical waste discarded in proper way (Eg: disposable syringe, blood } \\
\text { and body fluid splashes) }\end{array}$ & 74 & 73.80 \\
\hline
\end{tabular}

Table 4. Distribution of respondents by level of knowledge and practice about prevention on HBV infection $(\mathbf{n}=150)$.

\begin{tabular}{|l|l|l|l|l|l|}
\hline \multicolumn{3}{|c|}{ Knowledge } & \multicolumn{4}{c|}{ Practice } \\
\hline Level & Frequency & Percent (\%) & Level & Frequency & Percent (\%) \\
\hline Good & 121 & 81.07 & Satisfactory & 65 & 72.22 \\
\hline Satisfactory & 22 & 14.74 & Appreciable & 16 & 17.78 \\
\hline Poor & 7 & 4.69 & Below standard & 9 & 10.00 \\
\hline Total & 150 & 100 & Total & 90 & 100 \\
\hline
\end{tabular}


Table 5. Association of practice about transmission, and prevention of HBV infection with education, sex and age $(\mathrm{n}=90)$.

\begin{tabular}{|c|c|c|c|c|c|c|c|c|}
\hline \multirow{2}{*}{$\begin{array}{l}\text { Name of } \\
\text { variables }\end{array}$} & \multicolumn{4}{|l|}{ Transmission } & \multicolumn{4}{|l|}{ Prevention } \\
\hline & $\begin{array}{l}\text { Satisfactory } \\
\%(n)\end{array}$ & $\begin{array}{l}\text { Appreciable } \\
\%(\mathbf{n})\end{array}$ & $\begin{array}{l}\text { Below } \\
\text { Standard } \\
\%(n)\end{array}$ & $\chi^{2}$ & $\begin{array}{l}\text { Satisfactory } \\
\%(n)\end{array}$ & $\begin{array}{l}\text { Appreciable } \\
\%(\mathbf{n})\end{array}$ & \begin{tabular}{|l|} 
Below \\
Standard \\
\%(n) \\
\end{tabular} & $\chi^{2}$ \\
\hline $\begin{array}{l}\text { Education } \\
\text { Diploma } \\
\text { B.Sc }\end{array}$ & $\begin{array}{l}71.8(74) \\
70.2(33)\end{array}$ & $\begin{array}{l}17.5(18) \\
21.3910)\end{array}$ & $\begin{array}{l}10.7(11) \\
8.5(4)\end{array}$ & $\begin{array}{l}\chi^{2}=4.14 \\
\mathrm{df}=2 \\
\mathrm{p}=0.813\end{array}$ & $\begin{array}{l}83.5(86) \\
60.1(24)\end{array}$ & $\begin{array}{l}13.6(14) \\
14.9(7)\end{array}$ & $\begin{array}{l}2.9(3) \\
2.1(1)\end{array}$ & $\begin{array}{l}\chi^{2}=1.69 \\
\mathrm{df}=4 \\
\mathrm{p}=.003\end{array}$ \\
\hline $\begin{array}{l}\text { Sex } \\
\text { Male } \\
\text { Female }\end{array}$ & $\begin{array}{l}56.0(14) \\
74.4(93)\end{array}$ & $\begin{array}{l}28.0(7) \\
16.6(21)\end{array}$ & $\begin{array}{l}4.0(10) \\
8.8(11)\end{array}$ & $\begin{array}{l}\chi^{2}=3.469 \\
d f=2 \\
p=0.177\end{array}$ & $\begin{array}{l}8.4(21) \\
83.2(104)\end{array}$ & $\begin{array}{l}16.0(4) \\
13.6(17)\end{array}$ & $\begin{array}{l}0(0) \\
3.2(4)\end{array}$ & $\begin{array}{l}\chi^{2}=.887 \\
\mathrm{df}=2 \\
\mathrm{p}=.642\end{array}$ \\
\hline $\begin{array}{l}\text { Age } \\
<20 \text { Yrs } \\
20-30 \text { yrs } \\
30-40 \text { Yrs } \\
>40 \text { yrs }\end{array}$ & $\begin{array}{l}70.2(33) \\
78.4(58) \\
65.0(13) \\
33.3(3)\end{array}$ & $\begin{array}{l}19.1(9) \\
13.5(10) \\
25.0(5) \\
4.4(4)\end{array}$ & $\begin{array}{l}10.6(5) \\
8.1(8) \\
10.0(2) \\
22.2(2)\end{array}$ & $\begin{array}{l}\chi^{2}=8.75 \\
\text { df }=6 \\
p=0.186\end{array}$ & $\begin{array}{l}89.42(42) \\
81.1(60) \\
8.0(16) \\
77.8(7)\end{array}$ & $\begin{array}{l}8.5(4) \\
16.2(12) \\
15.0(3) \\
22.2(2)\end{array}$ & $\begin{array}{l}2.1(1) \\
2.7(2) \\
5.0(1) \\
0(0)\end{array}$ & $\begin{array}{l}\chi^{2}=3.0 \\
\mathrm{df}=2 \\
\mathrm{p}=.223\end{array}$ \\
\hline
\end{tabular}

Table 6. Association between knowledge and practice regarding prevention of $\mathrm{HBV}$ infection.

\begin{tabular}{|l|l|l|l|c|}
\hline \multicolumn{3}{|c|}{ Name of variables } & \multirow{2}{*}{$\chi^{2}$} \\
\cline { 2 - 4 } & Gnowledge level & \\
\hline Satisfactory & $66.7(10)$ & Satisfactory \%(n) & Poor \%(n) & $\chi^{2}=8.099$ \\
Appreciable & $78.6(22)$ & $33.3(5)$ & $0(0)$ & $\mathrm{df}=4$ \\
\hline Below standard & $86.9(93)$ & $14.3(4)$ & $7.1(2)$ & .088 \\
\hline
\end{tabular}

\section{Discussion}

This cross-sectional study was carried out among 150 student nurses to assess the current level of knowledge and practice regarding prevention of $\mathrm{HBV}$ infection who were attaining in selected nursing colleges and hospitals. In this study, we found that near to half participants were within the age groups belong to 20-30 years, with a mean age 24 years (SD \pm 6.150$)$ and nearly one third below 20 years. This findings contrast with others international studies. In an Arabian study by Modawi et al., in 2020 found that $81.7 \%$ respondent's age belong to 21-22 years and a Nepalese study Paudel et al., 2012 found 60.5\% were 18-20 years group. Majority (83.3\%) of respondents were female which is similar findings in an Indian study nearly $80 \%$ were female (Reang et al., 2015). Majority (75.3\%) of the respondents was Muslim which is opposite finding in previous study where 87.6\% was Hinduism (Paudel et al., 2012). Most of the respondent's (68.7\%) education level was Diploma in Nursing Program which was similar in previous studies where most of them (95.8\%) in Diploma Nursing program (Reang et al., 2015). It was observed that 37.3\% had income below BDT 10000 and $24.7 \%$ to $21 \%$ had BDT 1000-20000 and BDT 20001- 30000 respectively. This findings was nearly similar in an Indian study found $24.7 \%$ had a monthly family income 10000Rs-15000Rs (Reang et al., 2015) and Nepalese study noted $35.3 \%$ monthly family income were <10000Rs (Paudel et al., 2012). Majority (80.0\%) of the respondents had family history of negative of HBV infection. There is no study findings related such kind of information is exists.

In this study found that a large portion $(67.30 \%)$ of the respondents was not vaccinated, $11.90 \%$ complete vaccinated and $21.70 \%$ respondents were partially vaccinated. This finding was difference from a previous Indian study in Meerut where nursing students had $40 \%$ not vaccinated followed by $41 \%$ fully vaccinated, and $19 \%$ were partially vaccinated (Anand et al., 2020).

Regarding types of Hepatitis, most (92\%) of the respondents answered Hepatitis-B prevalent in our country which is consistent with a study in Agartala City, India found 99.7\% aware of HB virus (Reang et al., 2015). Majority (90.67\%) answered Hepatitis-B is serious types of Hepatitis. Hepatitis is a serious form hepatitis caused by a virus and $92.2 \%$ to $94.9 \%$ respondents say causative agent of Hepatitis-B (Paudel et al., 2012; Anand et al., 2020). Most of the respondents know the blood borne (93.33\%) and STD (89.33\%) is the sources of HBV infection. Besides, the majority of the respondents answered mode of transmission of HB Virus is through blood transfusion (96\%), sexual intercourse (89.33\%), and use of contaminated syringes, needles (88\%) 
and also trans-placental route $(83.33 \%)$. This finding is similar with an Indian study where found $91 \%$ say vertical transmission, $83.2 \%$ through needle stick injury, 63.1\% unsafe sex (Reang et al., 2015), and 97.7\% infected blood transfusion (Paudel et al., 2012). Nurses appeared to be the highest (89.33\%) risk person of HBV infection followed by doctor (78.67\%), multiple injecting drug user (82.67\%), and sexual worker (85.33\%). This finding was similar with Reang et al., (2015) found 80.2\% answered Doctor, Nurse, Lab Technologist are high risk group for HBV infection. Regarding symptoms of HBV infection, most of the respondents answered yellow coloration of sclera (92\%), followed by yellow coloration of urine $(92.67 \%)$, weakness $(90 \%)$, and anorexia $(84.67 \%)$. This finding was comparable with study in Nepal where found $82.2 \%$ yellow discoloration of eye, 71.7\% anorexia (Paudel et al., 2012) and in Saudi Arab found 58.3\% jaundice and dark urine (Modawi et al., in 2020). Majority of the respondents know the complication of HBV infection is cirrhosis of liver (95.33\%), loss of immunity (88.67\%), and liver cancer (70\%). This finding varies from previous study where $60 \%$ (Modawi et al., in 2020) to 73.0\% respondents (Paudel et al., 2012) stated complication of cirrhosis of liver and hepatic cancer. Most (86.0\%) of the students answered HBsAg is the investigation for HBV infection. The finding contradicts with an Arabian study where 58.3\% knew that blood test done for HBV infection in Saudi Arab (Modawi et al., in 2020) and also 53.5\% knew in India (Anand et al., 2020). Most (96\%) of the respondents know the vaccination is the way prevention of transmission of HBV infection. Then they also answered use of disposable syringe and needles (92.67\%), blood transfusion through screening (88.67\%), use of gloves $(84.67 \%)$, and safe sexual relationship (83.33\%). This findings matched with previous studies where $96.6 \%$ to $100 \%$ response HBV infection prevented by vaccine $89 \%$ avoid multiple sex partners, $94 \%$ to $100 \%$ students response use of sterile syringes and needles, $94 \%$ use of sterile gloves during injecting or drawing bloods (Paudel et al., 2012; Reang et al., 2015; Mahore et al., 2015).

Most (91.90\%) of students always strictly checking during blood transfusion and most (96\%) of them discarded HBV infected syringe and needles. This finding is similar with an Agartala study in India where $83.1 \%$ nursing students discarded the needles and syringes after use in a safe puncture proof container (Reang et al., 2015). Use of sterile instruments can be prevention of HBV infection in healthcare setting. Most of the respondents answered use in operational activities (99.33\%), followed by dressing (98\%), patients delivery (97.33\%), and catheterization $(91.33 \%)$. This findings similar with Indian study where most $(93.5 \%)$ of nursing student reported that use of sterile equipments before using for prevention of HBV infection. Most of the students nurses' answered wearing of gloves during patients delivery (98\%), dressing (94\%), and during patients care (91.33\%). This finding varies from previous studies where in India 94\% uses sterile gloves during injecting or drawing blood (Reang et al., 2015) but in Bangladesh 73\% uses gloves in hospital settings (Mehriban et al., 2014). Most of the students reported they do in duty hour's toward HBV infected patients sympathy and cooperation (93.33\%), maintain isolation (91.33\%), self protection from needle stick injury (94\%), and use of gloves nursing care $(84.67 \%$ ). Most of studies had found nursing students were facing accidental injury by sharp instruments like's needles, blade and blood exposure. This prevalence was found varies from $40.7 \%$ to $53.4 \%$ (Reang et al., 2015; Anand et al., 2020). This finding matched with previous study (Paudel et al., 2012; Reang et al., 2015; Anand et al., 2020). Majority of the student nurse's reported about advice of HBV infected patients take appropriate treatment (93.33\%), use of condom in sexual intercourse (96\%), and use of separate utensils likes brush, razor etc.(87.33\%). A study from Ethiopian university health sciences including nursing students stated that $76.5 \%$ response HBV is treatable (Gebremeskel et al., 2020). Study from Nepal has found 69.9\% response avoiding sharing razor and tooth brush (Paudel et al., 2012). On the topic of use of condom, it was observed in Bangladesh that only $42 \%$ said use of condom during sexual intercourse for preventive practice on Hepatitis-B (Mehriban et al., 2015). To promote public awareness, most of the respondents say to regular advertisement in media (98\%), awareness professional group (94\%), students group (91\%), and also strengthening community health services $(87.33 \%)$. This finding did not match with others internal study.

In our study found that most (81.07\%) of the respondents had good level knowledge about prevention on HBV infection. This finding is similar with a Nepalese study where $85.2 \%$ nursing students had a high level of knowledge on prevention Hepatitis-B (Paudel et al., 2012).

We also observed that majority (72.22\%) respondents performed do satisfactory level practice for prevention of HBV infection. This finding is contradicted with others global studies where found most of student's practices were not satisfactory (Reang et al., 2015) and poor level for prevention of HBV infection (Gebremeskel et al., 2020).

Practice on prevention of HBV infection was significant positive relationship with education $(\mathrm{p}<.005)$. This finding had similar with Paudel's study where education level was significantly correlation with the level knowledge on Hepatitis-B at $\mathrm{p}<.001$ (Paudel's et al., 2012). However, others had no significant relationship 
between practice of transmission and prevention of HBV infection with gender and ages of the respondents ( $p>05$ ). This findings also alike with previous study (Balegha et al., 2017).

In this study, there is no statistical significant association was found between knowledge and practice regarding prevention of HBV infection ( $\mathrm{p}>.05$ ). This finding contrary with a study in Dhaka, had found a positive significant association was found between level of nurses knowledge and level of preventive practice regarding HBV infection at $\mathrm{p}<.001$ (Mehriban et al., 2015).

\section{Conclusions}

The overall knowledge of HBV infection was good level among study participants. Moreover, majority of their practices performed do satisfactory level practice for prevention of HBV infection. Although, there is no statistical significant association was found between level of knowledge and level of practice regarding prevention of HBV infection. Hospitals Authority should be arranging a program to coverage vaccination status of student nurses. In addition, arrange regular training and seminar to increase and maintain continue good level of knowledge and practice for prevention of HBV infection for both save of patients and nurses.

\section{Acknowledgements}

Thanks to Dr. Syed Alamgir Safwath, Former Assistant Professor, Department of Gastroenterology at Sylhet MAG Osmani Medical College Hospital for his contribution to ensue Questionnaire validation in this research. We'd like to offer our heartfelt gratitude to all of the student nurses who took part in this research.

\section{Conflict of interest}

None to declare.

\section{Authors' contribution}

Muhammad Nurul Islam: conceptualizing, methodology, data collection, manuscript writing, reviewing and editing.

Kazi Jahangir Hossain: conceptualizing, methodology and data analysis.

\section{References}

Abdela A, B Woldu, K Haile, B Mathewos and T Deressa, 2016. Assessment of knowledge, attitudes and practices toward prevention of hepatitis B virus infection among students of medicine and health sciences in Northwest Ethiopia. BMC Res. Notes, 9: 410.

Akazong E, C Tume, R Njouom, L Ayong, V Fondoh and JR Kuiate, 2020. Knowledge, attitude and prevalence of hepatitis B virus among healthcare workers: a cross-sectional, hospital-based study in Bamenda Health District, NWR, Cameroon. BMJ Open, 10: e031075.

Al Mahtab M, S Akhter, KU Mollick, MH Uddin, SI Khan and SM Akbar, 2017. Prevalence of Hepatitis B virus and Hepatitis $C$ virus in a tea garden of Bangladesh. Euroasian J. Hepato-gastroenterol, 7:107.

Anand K, S Jain, SK Garg, A Kumar and C Mittal, 2020. Assessment of Knowledge, attitude and practices regarding Hepatitis-B among nursing students. IOSR J. Dent. Med. Sci., 19: 30-35.

Balegha AN, A Yidana and GA Abiiro, 2021. Knowledge, attitude and practice of hepatitis B infection prevention among nursing students in the Upper West Region of Ghana: A cross-sectional study. PloS One, 16: e0258757.

CDC, 2021. Viral Hepatitis/Hepatitis-B. Available https://www.cdc.gov/hepatitis/HBV/index.htm

Chang MH, SL You, CJ Chen, CJ Liu, MW Lai, TC Wu, ... and YS Cheng, 2016. Long-term effects of hepatitis B immunization of infants in preventing liver cancer. Gastroenterology, 151: 472-480.

Choudhuri G, V Gupta, TS Negi and R Ojha, 2019. Potential implications of detecting HBsAg in asymptomatic people in an endemic community through Medical Camps. J. Clin. Experi. Hepato, 9: 43-49.

Collaborators GBD, 2018. Global, regional, and national incidence, prevalence, and years lived with disability for 354 diseases and injuries for 195 countries and territories, 1990-2017: a systematic analysis for the Global Burden of Disease Study 2017.

Demsiss W, A Seid and T Fiseha, 2018. Hepatitis B and C: seroprevalence, knowledge, practice and associated factors among medicine and health science students in Northeast Ethiopia. PLoS One, 13: e0196539.

Gebremeskel T, T Beshah, M Tesfaye, B Beletew, A Mengesha and A Getie, 2020. Assessment of knowledge and practice on Hepatitis B infection prevention and associated factors among health science students in Woldia University, Northeast Ethiopia. Adv. Preventive Med., 2020: 1-6. 
Hasan KN, MA Khaleque, NA Shejuti, T Wasi and S Islam, 2017. Prevalence of Hepatitis B virus seromarkers and associated risk factors in young healthy individuals in Bangladesh: Implications for preventive strategies. Hepat Mon, 17: e1424.

Health Bulletin 2019, 2020. Communicable Disease Control. Published by Management Information System, Director General Health Services, Dhaka. Available https://www.dghs.gov.bd/images/docs/Publicaations /Health\%20Bulletin\%202019\%20Print\%20Version\%20 (2)-Final.pdf

Hepatitis-B Foundation, 2020. Hepatitis B facts and figures. Available https://www.hepb.org/what-is-epatitisb/what-is-hepb/facts-and-figures/

Hossain MM, AN Alam, M Siddiqua, A Siddika and A Nessa, 2018. Immune response among the children to hepatitis B vaccination: A community-based study in Bangladesh. Bangladesh Med. Res. Counc. Bull, 44: 103-108.

Irmak Z, B Ekinci and AF Akgul, 2010. Hepatitis B and C seropositivity among nursing students at a Turkish university. Int. Nurs. Rev., 57: 365-369.

Khan NR, Riya S, Islam MS and HA Majeed, 2017. Knowledge and preventive practice regarding hepatitis B among the nurses in Dhaka medical college hospital. J. Dhaka Med. Coll., 26: 36-42.

Karadag M, 2010. Occupational exposure to blood and body fluids among a group of Turkish nursing and midwifery students during clinical practise training: frequency of needle stick and sharps injuries. Japan J. Nurs Sci, 7: 129-135.

Lim JK, MH Nguyen, WR Kim, R Gish, P Perumalswami and IM Jacobson, 2020. Prevalence of chronic hepatitis B virus infection in the United States. Am. J. Gastroenterol, 115: 1429-1438.

Mahtab MA, S Rahman, MF Karim, M Khan, G Foster, S Solaiman and S Afroz, 2008. Epidemiology of hepatitis B virus in Bangladeshi general population. Hepatobiliary \& pancreatic diseases international: HBPD INT, 7: 595-600.

Mahtab MA, 2015. Epidemiology of viral hepatitis and liver diseases in Bangladesh. Euroasian J. Hepatogastroenterol, 5: 26.

Mehriban N, GU Ahsan and T Islam, 2014. Knowledge and preventive practices regarding Hepatitis B among nurses in some selected hospitals of Dhaka city, Bangladesh. South East Asia Journal of Public Health, 4: 48-52.

Modawi HA, MB Mohamed, IKA Gadir, NH Ahmed and KMI Zaeri, 2020. Knowledge, attitude, and practice (KAP) about Hepatitis B infection among nursing students in Sabya College, Saudi Arabia. Electronic Physician, 12: 7752-7758.

Nalli SK, T Sinha, G Arora and QH Khan, 2017. A study on knowledge attitude and practices related to hepatitis B infection among nursing students of government nursing college, Jagdalpur, Bastar, Chhattisgarh. Int. J. Com. Med. Public Health, 4: 3407-3412.

Paudel DP, SK Prajapati and DP Paneru, 2012. Hepatitis B related knowledge and perception of nursing students: an institutional based study in Kathmandu, Nepal. Int. J. Health Sci. Res., 2: 57-66.

Pérez-Diaz C, OJ Calixto, ÁA Faccini-Martínez, JS Bravo-Ojeda, CA Botero-García, E Uribe-Pardo, ... and J Osorio, 2015. Occupational exposure to blood borne pathogens among healthcare workers: a cross-sectional study of a registry in Colombia. J. Occu. Med. Toxico, 10: 1-7.

Reang T, T Chakraborty, M Sarker and A Tripura, 2015. A study of knowledge and practice regarding Hepatitis B among nursing students attending tertiary care hospitals in Agartala city. Int. J. Res. Med. Sci., 3: 16411649.

Schmit N, S Nayagam, MR Thursz and TB Hallett, 2021. The global burden of chronic hepatitis B virus infection: comparison of country-level prevalence estimates from four research groups. Int. J. Epidmiol., 50: 560-569.

Swarnalatha N, 2014. Do nursing students know about hepatitis B? A study from nursing college in Tamil Nadu. Int J. Health Rehabil Sci., 3: 69-74.

Uz-Zaman MH, A Rahman and M Yasmin, 2018. Epidemiology of Hepatitis B virus infection in Bangladesh: Prevalence among general population, risk groups and genotype distribution. Genes, 9: 541.

WHO, 2020. Hepatitis B. Available: https://www.who.int/news-room/fact-sheets/detail/hepatitis-b 